\title{
Determinants of Foreign Direct Investment in the Middle East Region: An Empirical Analysis
}

\author{
Munir Hassan ${ }^{1}$ \\ ${ }^{1}$ Faculty Member, Economics Department, Kuwait University, Kuwait \\ Correspondence: Munir Hassan. E-mail: munir25739@yahoo.com
}

Received: February 21, 2017

Accepted: March 24, 2017

Online Published: October 28, 2017

doi:10.5539/ass.v13n11p47

URL: https://doi.org/10.5539/ass.v13n11p47

\begin{abstract}
The objective of the present study is to examine the Foreign Direct Investment (FDI) inflows in the Middle East region, and it also attempts to identify the potential determinants for the investment inflows. With this purpose taking assistance of public database such as the World Bank (WB), and the United Nations Conference on Trade and Development (UNCTAD) a panel econometric model has been specified and tested for a sample of 09countries over a period of 35 years (1981-2015). The result of the study shows Purchasing Power, Human Capital and Trade Openness as the key determinants of Inward FDI inflows for the growth and development of the Middle East region.
\end{abstract}

Keywords: FDI, Middle East, Human Capital, GDP

\section{Introduction}

Foreign direct investment is a continuous and emergent source of finance, helping developing countries to counter the gap in technology in comparison with high-income countries. It also helps to upgrade managerial skills along with developing exports market (World Bank, 1993). Foreign Direct Investment (FDI) inflows into the main sectors of the economy are assumed to play an integral role. This is due to it being a source of capital, transfer of management expertise and technology in countries of transition economies, implying positive effects of FDI on a host economy's development effort (Sahoo, Mathiyazhagan, \& Parida, 2001). FDI is not only a source of finance for economies in transition but also a means of acquiring technology, skills, organizational and managerial practices and provides access to markets. It has been also observed that greater are the expectations of a less developed country from FDI to alleviate its resource and skills limits.

But in case of Middle East countries growth has been hampered due to causes such as lack of human capital, harsh weather conditions, the local customs and traditions, relatively low participation of women in the labor force comparing with world average, issues related to transparency, the level of corruption, and the inability of oil producing countries to commit to an industrial diversification program producing competitive products worldwide. Due to all of these unfortunate reasons the ability to attract FDI for Middle East has serious implications. In recent years, however, within the economies of the Middle East, many of the nations have realized the importance of FDI in accelerating economic development. Middle East states with large reservoirs of energy resources such as gulf nations seek to expand and diversify operations with the help of FDI. Even countries with no or little energy resources (e.g. Jordan and Lebanon) are looking for opportunities from abroad in the form of investment that will bring growth prospects for them.

The objective of the present study is to expound an overview of the current scenario of FDI inflows in the Middle East through analyzing the potential determinants of FDI inflows in the region. The study is based on the selected countries of the Middle East region due to the limited data availability on the websites of UNCTAD and World Bank Database.

\section{FDI inflows in the Middle East}

Middle East countries are at a vital development stage. The World Bank projected that the region needs to create 100 million jobs by 2020 to stay up-to-date with the population growth (Marktanner \& Salman, 2011; van der Zwaan et al., 2013). In 2000, the region lagged behind other countries in attracting FDI, receiving only $0.4 \%$ of global investments (Ditchtl \& Drobetz, 2011; UNCTAD, 2016). According to UNCTAD information, the FDI in Middle East experienced an increase in FDI inward between 2002 and 2010, especially the Gulf Cooperation 
Council (GCC) countries (Toone,2012). FDI in the Middle East is unusual in many wayswhen compared with the rest of the world. It has been characterized by four main features as firstly, the pace of FDI flows globally is much higher than the flows of Middle East which has resulted in lower average stocks. This is when compared with the world average. Secondly, only handful of countries has received a good portion of FDI flows and it has remained concentrated in few sectors. This concentration has led to limited investment scope and low in productive employment generation. In the period of transition that which has gone to the public sector has been episodic and has remained attached to the one time privatization waves. Thirdly, the gross fixed capital formation and gross domestic product has shown a small portion of FDI stocks and flows for the region's economies. The only good news in the present context is that the recent evidence suggest that the intra-arab investment comprises of a significant portion of FDI inflows in the region which may be underestimated in international financial statistics (Eid \& Fiona, 2003).

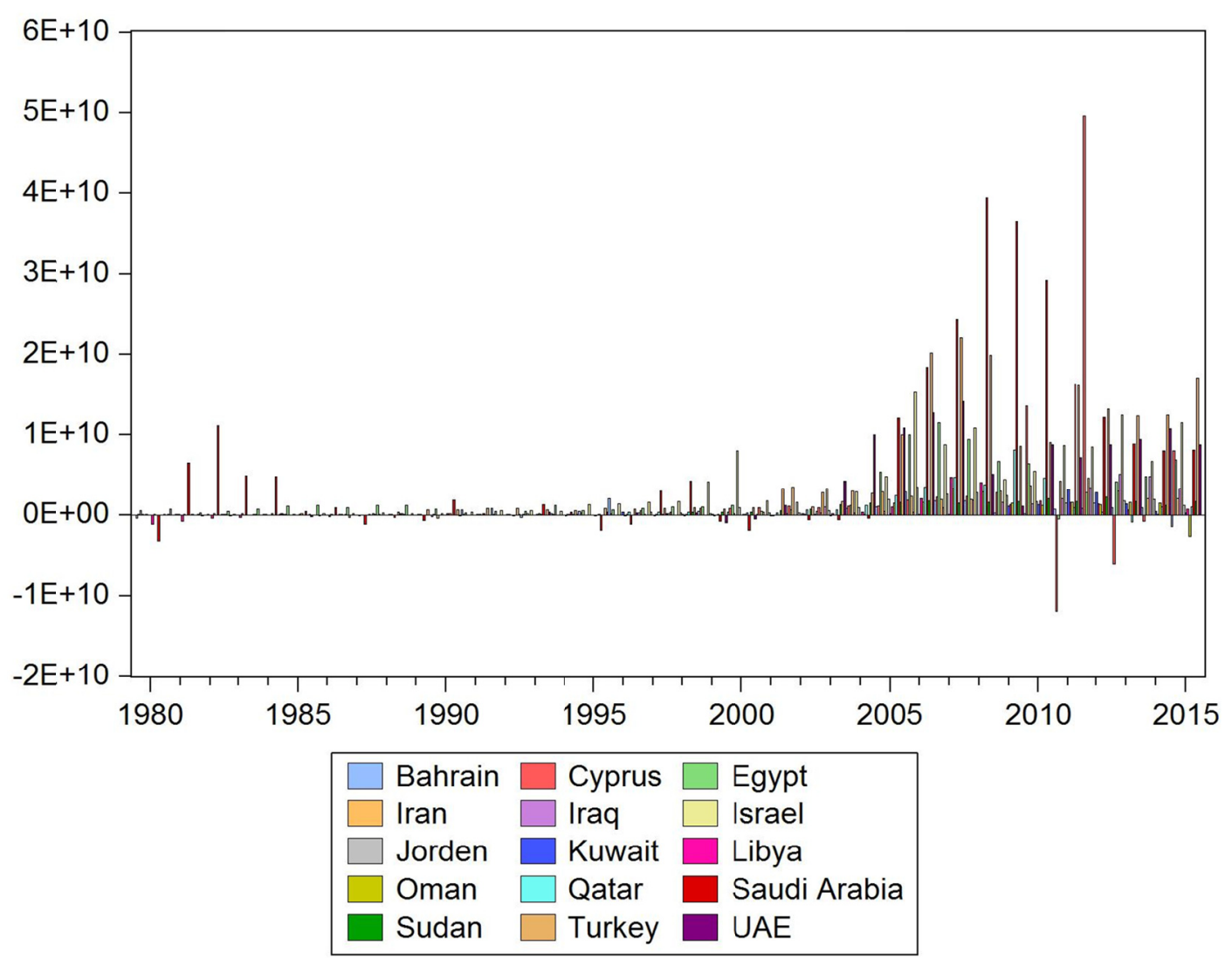

Figure 1. Pattern of FDI inflows in the countries of the Middle East region (US\$ millions) Source: The World Bank Database, 2017

FDI inflows in the selected countries of Middle East have been shown in the Figure 1. It is showing growth in the FDI inflows in the countries of the Middle East region. Continuous efforts have been made to improve the pace of FDI inflows in most of the countries of Middle East region by creating investment zones, investment promotion agencies, provisions for special incentives and tax breaks. Foreign Direct Investment is taken as an effective tool for adding to the existing resources in the form of capital, technology, human capital and others, facilitating rates of growth important for economic development. FDI is considered over and above portfolio investment due to its long term nature. Other added benefit of FDI is that it is less volatile source of capital. Research also highlights that FDI is preferred to foreign aid (Trevino \& Upadhyaya 2003) having a positive impact (Trevino, Daniels, \& Arbelaez, 2002).

\section{Literature Review}

The foremost model for determining the drivers of Foreign Direct Investment instigates from the authoritative work of Dunning $(1973,1981)$ that offer a complete analysis and interpretation on the parameters such as ownership, location and the internationalization (OLI) paradigm. Agarwal (1980) and Schneider et al (1985) 
have worked on identifying empirical evidence with the help of aggregate econometric approaches. There is support in the literature on the importance of identifying determinants of FDI and its substantial impact on growth. There is also evidence from the existing literature that existing FDI theories have partially remained successful in explaining the growth phenomenon (Lall \& Narula, 2004; Blonigen, 2005).

The results of the previous researches on the determinants of FDI inflows to the Middle East have been somewhat inconsistent, the same determinants are found to be significant by some authors and insignificant by others. Onyeiwu (2003) explored the determinants of FDI in the Middle Eastern countries. By analyzing a number of institutional and macroeconomic factors, the study shows that few of the significant determinants of Foreign Direct Investment inflows to developing countries are not statistically significant in determining FDI inflows to the Middle East countries. These comprises of economic growth, infrastructure, inflation, and rate of return on investment. Only trade openness and corruption (i.e. bureaucratic red tape) were found significant in the Middle East. Therefore, the study concludes that trade liberalization and privatization plays a more conclusive role than macroeconomic stabilization strategies in determining FDI inflows to the Middle East. In an another study by Elfakhani \& Matar (2007), shows fairly different findings from the earlier one as, the last year's Foreign Direct Investment, country openness, return on investment, membership of WTO and being an oil-exporting country are all significant forecasters of country FDI inflows for the Middle Eastern and North African region. However, the results of this study are dependent on time as few of the variables are significant during the first sub-period, while others are significant in the second sub-period. Further, Abumangosha (2014) in his thesis examined the determinants of Foreign Direct Investment for countries of the Middle East and North Africa (MENA) region by conducting an empirical analysis at three different levels i.e., intra-regional level, country-level and firm-level. The study shows that FDI inflows differ between MENA countries according to their economic and institutional structure. As resource-rich countries on an average receive less FDI compared resource-poor countries in the MENA region. Moreover, FDI to resource-poor countries responds negatively to the availability of natural resource, and positively to the quality of institutions, and vice versa in case of resource-rich countries.

The present study adds to the existing literature by analyzing for possible FDI determinants specific to the Middle East region.

Based on the objective of the study and review of literature following are the potential variables selected in the study for determining FDI inflows in the Middle East. The variables are categorized in to five broad categories, viz., Purchasing Power, Market size, Gross Capital Formation, Inflation, Human Capital and Trade Openness.

\subsection{Purchasing Power}

The relationship between GDP per capita and FDI is both direct and indirect and for GDP per capita it is assumed reflective of the economic well-being of a citizen. Whether a citizen is better or worse off is determined on the basis of this indicator, i.e., GDP per capita. This in turn is an indicator of the purchasing power of the citizens and becomes important for the investors for giving priority to one country over other. (Asiedu, 2002; Callen, 2008). This means that a higher GRP per capita may attract more foreign direct investment into a country.

\subsection{Market Size}

Larger market size countries should receive more investment inflows than that of small market size countries. It is generally measured by Gross Domestic Product (GDP), GDP growth rate. It is expected to have a positive determinant of FDI inflows (Resmini, 2000; Garibaldi et al., 2002). The present study deploys GDP growth rate as a proxy variable for market size.

\subsection{Gross Capital Formation}

Also known as gross domestic investment, it is the summation of the expenditures on additions to the long-term fixed assets of the economy with net changes in the level of stock (World Bank, 2017).In emerging economies and transition economies, investment climate is to key to attract foreign direct investment. When more funds are invested, the economy achieves higher Gross Capital formation that further leads to higher economic growth (Libor Krkoska, 2001; Lipsey, 2000)

\subsection{Inflation}

One of macroeconomic variable is rate of inflation playing a critical role in attracting inflow of foreign investment. A very high rate of inflation signals instability and erosion of the purchasing power associated with inappropriate government policies, especially the monetary-fiscal policy mix while low inflation rate shows vice versa impact (Macpherson, 2013; Khan \& Mitra, 2014). It is argued that the possible linkages between rate of 
inflation and economic growth along with the involvement of foreign direct investment leads to accelerated economic growth in favour of the host countries (Huybens \& Smith, 1999; Boyd, Levine, \& Smith, 2001).

\subsection{Human Capital}

Human Capital as national resource is in the form of skills and abilities of the people. When put to productive use it becomes an important determinant of the long-term economic success of the nation. The human capital is leveraged in order to generate considerable returns for individual and society. In line with endowment theory, it is assumed that more labour force will attract more MNCs due to cheap availability of labour. Thus, the quantity of the labour force in the host country shall have a positive impact on the FDI inflows. In the present study labour force has been used as a proxy for Human Capital.

\subsection{Trade Openness}

Trade Openness is considered worldwide by companies and countries as an indicator of better investment climate. Therefore, it is postulated as a determinant of FDI in the existing literature. Trade openness is commonly expected to be a positive determinant of FDI. Trade openness is proxied as the ratio of the Export plus Import divided by GDP (Asiedu, 2002; Sahoo, 2006).

\section{Hypotheses of the Study}

$\mathrm{H}_{01}$ : The relationship between Purchasing Power and Inward FDI is positive for Middle East

$\mathrm{H}_{02}$ : The relationship between Market Size and Inward FDI is positive for Middle East.

$\mathrm{H}_{03}$ : The relationship between Infrastructure and Inward FDI is positive for Middle East.

$\mathrm{H}_{04}$ : The relationship between Inflation and Inward FDI is negative for Middle East.

$\mathrm{H}_{05}$ : The relationship between Human Capital and Inward FDI is positive for Middle East.

$\mathrm{H}_{06}$ : The relationship between Trade Openness and Inward FDI is positive for Middle East.

\section{Data and Research Methodology}

The variables included in the study are Inward FDI, Purchasing power, Market Size, Gross Capital Formation, Inflation, Human Capital and Trade Openness. Inward FDI is the dependent variable and the remaining are explanatory variables. Table 1 describes the characteristics of the variables.

Panel OLS Regression Model is used for empirical investigation. Hausman Test (1978) is used to decide whether to use Fixed Effect Panel Regression Model or Random Effect Panel Regression Model. The hypothesis for Hausman Test Model is:

$\mathrm{H}_{0}$ : Random Effect Model is appropriate

$\mathrm{H}_{1}$ : Fixed Effect Model is appropriate

If the prob. value of Hausman Test is less than 0.05 , the null will be rejected otherwise alternative will be accepted. UNCTAD Statistics and World Bank Database are used for data extraction.

Table 1. Description of Variables

\begin{tabular}{ccccc}
\hline Variable & Determining Factors & Type & Symbol & Data Sources \\
\hline FDI Inflows & Inward FDI & Dependent & FDI & World Bank \\
GDP Per Capita & Purchasing Power & Independent & GDPPC & UNCTAD \\
GDP Growth Rate & Market Size & Independent & GDPGR & World Bank \\
Gross Capital Formation (\% of GDP) & Gross Capital Formation & Independent & GCF & World Bank \\
Inflation, GDP deflator (annual \%) & Inflation & Independent & INF & World Bank \\
Labour Force & Human Capital & Independent & LBR & UNCTAD \\
Trade as a $\%$ of GDP & Trade Openness & Independent & TO & World Bank \\
\hline
\end{tabular}

Source: Prepared by the researcher

\section{Data Analysis and Results}

Table 2 presents the descriptive statistics of the panel of Middle East region for the period from 1981 to 2015 i.e. for 35 years. 
Table 2. Descriptive Statistics for Panel Data

\begin{tabular}{llllllll}
\hline & FDI & GDPPC & GDPGR & GCF & INF & LBR & TO \\
\hline Mean & $2.54 \mathrm{E}+09$ & 10244.52 & 4.243561 & 22.68595 & 16.07031 & 7138.004 & 76.35733 \\
Median & $6.05 \mathrm{E}+08$ & 11245.05 & 4.482454 & 21.70873 & 6.669434 & 2204.052 & 79.49446 \\
Maximum & $4.96 \mathrm{E}+10$ & 27071.04 & 18.67244 & 46.02747 & 390.6788 & 30327.46 & 149.4534 \\
Minimum & $-1.19 \mathrm{E}+10$ & 481.7762 & -13.45211 & 4.329239 & -25.12813 & 146.9700 & 11.08746 \\
Std. Dev. & $5.93 \mathrm{E}+09$ & 7835.240 & 4.080555 & 6.234609 & 36.13075 & 8516.067 & 32.52605 \\
Skewness & 4.021833 & 0.238408 & -0.427648 & 0.556116 & 5.497532 & 1.113276 & 0.014583 \\
Kurtosis & 24.69056 & 1.821550 & 5.530686 & 4.000203 & 46.65551 & 2.917628 & 2.293825 \\
Observations & 315 & 315 & 315 & 315 & 315 & 315 & 315 \\
\hline
\end{tabular}

Source: Prepared by the researcher using eviews output

The study empirically uses the Panel Regression (OLS) with either Fixed or Random Effect Model depending on the rejection of null hypothesis of Hausman Test. Hausman Test captures the correlated random effects and is conducted on the output generated by Random Effect Regression Model (Iqbal, B.A., Rahman, M.N. \& Hassan, M., 2016). Table 3 presents the output of the test.It is clear from the table 3 that the probability value of Hausman Test is more than $0.05(0.0826)$, therefore, null hypothesis stands accepted.

Table 3. Hausman Test Result

\begin{tabular}{llll}
\hline Correlated Random Effects - Hausman Test & & & \\
\hline Test cross-section random effects & & & Prob. \\
Test Summary & Chi-Sq. Statistic & Chi-Sq. d.f. & 0.0826 \\
Cross-section random & 11.194382 & 6 & \\
\hline
\end{tabular}

Source: Prepared by the researcher using eviews output

The Null Hypothesis of Hausman Test that 'Random Effect Model is appropriate' and its acceptance signifies that the appropriate model for the sample panel data for Middle East is Random Effect Regression Model. The model specification is as follows:

$\mathrm{FDI}=\beta_{0}+\beta_{1} \mathrm{GDPPC}+\beta_{2} \mathrm{GDPGR}+\beta_{3} \mathrm{GCF}-\beta_{4} \mathrm{INF}+\beta_{5} \mathrm{LBR}+\beta_{6} \mathrm{TO}+\varepsilon_{\mathrm{it}}$

The probable signs are mentioned in the specified model and the parameters would be estimated with the help of Random Effect Regression Model as suggested by Hausman Test. The output of Random Effect Regression Model is given in Table 4.

Table 4. Random Effect Panel Regression Model Output

\begin{tabular}{|c|c|c|c|c|}
\hline Variable & Coefficient & Std. Error & t-Statistic & Prob. \\
\hline $\mathrm{C}$ & $-1.48 \mathrm{E}+10$ & $2.31 \mathrm{E}+09$ & -6.391539 & $0.0000 *$ \\
\hline GDPPC & 551992.7 & 129131.3 & 4.274662 & $0.0000 *$ \\
\hline GDPGR & 37379673 & 70936873 & 0.526943 & 0.5986 \\
\hline GCF & 44459762 & 53993752 & 0.823424 & 0.4109 \\
\hline INF & -8885700 & 9363670. & -0.948955 & 0.3434 \\
\hline LBR & 764372.3 & 122639.7 & 6.232664 & $0.0000^{*}$ \\
\hline TO & 68021777 & 25920803 & 2.624216 & $0.0091 *$ \\
\hline R-squared & 0.349488 & \multicolumn{2}{|c|}{ Mean dependent var } & $2.54 \mathrm{E}+09$ \\
\hline Adjusted R-squared & 0.319130 & \multicolumn{2}{|c|}{ S.D. dependent var } & $5.93 \mathrm{E}+09$ \\
\hline S.E. of regression & $4.89 \mathrm{E}+09$ & \multicolumn{2}{|c|}{ Akaike info criterion } & 47.50541 \\
\hline Sum squared resid & $7.17 \mathrm{E}+21$ & \multicolumn{2}{|c|}{ Schwarz criterion } & 47.68410 \\
\hline Log likelihood & -7467.102 & \multicolumn{2}{|c|}{ Hannan-Quinn criter. } & 47.57680 \\
\hline F-statistic & 11.51250 & \multicolumn{2}{|c|}{ Durbin-Watson stat } & 1.353883 \\
\hline Prob(F-statistic) & 0.000000 & & & \\
\hline
\end{tabular}

*indicates significant values at $5 \%$ level of significance

Source: Prepared by the researcher through the output of eviews. 
The Rsquare of the accepted model is 0.349488 which means that the explanatory variables are able to explain about $34 \%$ of the variation in the Inward FDI flows for the Middle East Region. The probability value of F-statistic for the model is 0.0000 which is less than 0.05 indicating that model is fit. Of six independent variables, three are significant. GDP Growth Rate (GDPGR), Gross Capital Formation (GCF) and Inflation (INF) are insignificant based on probability values. The analysis shows that for Middle East, the determinants of Inward FDI consist of Purchasing Power, Human Capital, and Labour Force. The results of hypotheses are summarized in Table 5.

Table 5. Summary of Hypotheses

\begin{tabular}{lcc}
\multicolumn{1}{c}{ Hypotheses } & $\begin{array}{c}\text { Prob. } \\
\text { value }\end{array}$ & $\begin{array}{c}\text { Acceptance/ } \\
\text { Rejection }\end{array}$ \\
\hline $\mathrm{H}_{01}$ :The relationship between Purchasing Power and Inward FDI is positive for Middle East. & 0.0000 & Accepted \\
$\mathrm{H}_{02}$ : The relationship between Market Size and Inward FDI is positive for Middle East. & 0.5986 & Rejected \\
$\mathrm{H}_{03}$ : The relationship between Infrastructure and Inward FDI is positive for Middle East. & 0.4109 & Rejected \\
$\mathrm{H}_{04}$ : The relationship between Inflation and Inward FDI is negative for Middle East. & 0.3434 & Rejected \\
$\mathrm{H}_{05}$ : The relationship between Human Capital and Inward FDI is positive for Middle East. & 0.0000 & Accepted \\
$\mathrm{H}_{06}$ : The relationship between Trade Openness and Inward FDI is positive for Middle East. & 0.0091 & Accepted \\
\hline
\end{tabular}

Source: Prepared by the researcher

\section{Conclusion}

Therefore, the study has highlighted the pattern of FDI inflows in the Middle East region by presenting the data related to FDI Inflows. As FDI in the Middle East is lowest when compared with the other countries around the world, thus need has been felt to increase the investment inflows for its sustainable development. Further the present study contributes to the existing literature by providing an overview of the pattern of FDI inflows in the Middle East countries. Onthe basis of the sample data of 9countries of Middle East Region having seven variables, it is concluded that Purchasing Power, Human Capital and Trade Openness are the key drivers of Inward FDI inflows for the growth and development of the Middle East region.

\section{References}

Abumangosha, S. (2014). Determinants of Foreign Direct Investment in MENA Region. Bournemouth University (Doctoral thesis). Retrieved from http://eprints.bournemouth.ac.uk/21779/1/ABUMANGOSHA\%2C\%20 Sala\%20M._Ph.D._2014.pdf

Agarwal, J. P. (1980). Determinants of foreign direct investment: a survey. Weltwirtschaftliches Archiv, 116, 739-77.

Asiedu, E. (2002). On the Determinants of Foreign Direct Investment to Developing Countries: Is Africa Different? World Development, 30(1), 107-119. https://doi.org/10.1016/S0305-750X(01)00100-0

Iqbal, B. A., Rahman, M. N., \& Hassan, M. (2016). MNCs and their role and contribution in Latin American countries. Transnational Corporations Rev., 8(2), 151-164. https://doi.org/10.1080/19186444.2016.1197476

Blonigen, B. A. (2005). A Review of the Empirical Literature on FDI Determinants, Atlantic Economic Journal, 33, 383-403. https://doi.org/10.1007/s11293-005-2868-9

Boyd, J. H., Levine, R., \& Smith, B. D. (2001). The Impact of Inflation on Financial Sector Performance, Journal of Monetary Economics, 47, 221-248. https://doi.org/10.1016/S0304-3932(01)00049-6

Callen, T. (2008). Back to Basics. What Is Gross Domestic Product? Finance \& Development. Retrieved from http://www.imf.org/external/pubs/ft/fandd/2008/12/pdf/basics.pdf

Ditchtl, H., \& Drobetz, W. (2011). Dollar-cost averaging and prospect theory investors: An explanation for a popular investment strategy. Journal of Behavioral Finance, 12(1), 41-52. https://doi.org/10.1080/15427560.2011.555029

Dunning, J. H. (1973).The determinants of international production. Oxford Economic Papers, 25. Stable URL: http://www.jstor.org/stable/2662317

Dunning, J. H. (1981). International production and multinational enterprise. Allen \&Unwin, London.

Eid, F., \& Paua, F. (2002). Foreign Direct Investment in the Arab World: The Changing Investment Landscape. Global Competitiveness Reports. World Economic Forum. 
Elfakhani, S. M., \& Matar, L. M. (2007). Foreign direct investment in the Middle East and North Africa Region. J. Global Business advancement, 1(1), 49-70. https://doi.org/10.1504/JGBA.2007.012549

Garibaldi, P., Mora. N., Sahay. R. and Zettelmeyer. J. (2002). What moves capital to transition economies?. IMF working paper, $\mathrm{WP} / 02 / 64$.

Huybens, E., \& Smith, B. (1999).Inflation, Financial Markets, and Long-run Real Activity, Journal of Monetary Economics, 43, 283-315. https://doi.org/10.1016/S0304-3932(98)00060-9

Khan, G. S., \& Mitra, P. (2014).A Causal Linkage between FDI Inflows with Select Macroeconomic Variables in India - An Econometric Analysis. IOSR Journal of Economics and Finance, 5(5), 2321-5933.

Lall, S., \& Narula, R. (2004). Foreign Direct Investments and its Role in Economic Development: Do We Need a New Agenda? The European Journal of Development Research, 16(3), 447-464.

Libor, K. (2001). Foreign direct investment financing of capital formation in Central and Eastern Europe. European Bank for Reconstruction and Development Working paper, 67.

Lipsey, R. E. (2000).Interpreting developed countries' foreign direct investment. NBER Working paper, 7810. Retrieved from https://core.ac.uk/download/pdf/6501775.pdf

Macpherson, D. (2013). Economics: Private and Public Choice. Mason: Cengage Learning.

Marktanner, M., \& Salman, L. (2011). Economic and geopolitical dimensions of renewable vs. nuclear energy in North Africa. Energy Policy, 39, 4479-4489. https://doi.org/10.1016/j.enpol.2010.12.047

Onyeiwu, S. (2003). Analysis of FDI Flow to Developing Countries: Is the MENA Region Different? Retrieved from http://www.mafhoum.com/press6/172E11.pdf

Resmini, L. (2000). The determinants of foreign direct investment into the CEECs: new evidence from sectoral patterns. Economics of Transition, 8(3), 665- 689. https://doi.org/10.1111/1468-0351.00060

Sahoo, D., Mathiyazhagan M. K., \& Parida, P. (2002). Is Foreign Direct Investment an engine of Growth? Evidence from the Chinese Economy. Savings and Development, 4, 419-439. Stable URL: http://www.jstor.org/stable/25830810

Sahoo, P. (2006). Foreign Direct Investment in South Asia: Policy, Trends, Impact and Determinants. $A D B$ Institute Discussion paper, 56.

Schneider, F., \& Frey, B. S. (1985). Economic and Political Determinants of Foreign Direct Investment. World Development, 13(2), 161-175. https://doi.org/10.1016/0305-750X(85)90002-6

Toone, J. E. (2012). Mirage in the Gulf? Examining the upsurge in FDI in the GCC and its legal and economic implications for the MENA region. Emory International Law Review, 26, 677-731. Retrieved from http://law.emory.edu/eilr/content/volume-26/issue-2/articles/mirage-in-the-gulf.html

Trevino, L. J., Daniels, J. D., \& Arbelaez, H. (2002). Market reform and FDI in Latin America: An empirical investigation. Transnational Corporations, 11(1), 29-48.

Trevino \& Upadhyaya, K. (2003). Foreign Aid, FDI and Economic Growth: Evidence from Asian Countries. Transnational Corporations, 12(2), 119-135. Stable URL: http://economicsbulletin.vanderbilt.edu/2007/ volume6/EB-07F20001A.pdf

United Nations Conference on Trade and Development (UNCTAD). (2016). UNCTAD Conferences. Retrieved from http://unctad.org/en/Pages/Meetings/UNCTADConferences.aspx

Van der Zwaan, B., Cameron, L., \& Kober, T. (2013). Potential for renewable energy jobs in the Middle East. Energy Policy, 60, 296-304. https://doi.org/10.1016/j.enpol.2013.05.014

World Bank. (1993). Global economic prospects and the developing countries 1993: summary. Global Economic Prospects and the Developing Countries (GEP).Washington, DC. The World Bank. Retrieved from http://documents.worldbank.org/curated/en/739051468779674087/Global-economic-prospects-and-the-dev eloping-countries-1993-summary

\section{Copyrights}

Copyright for this article is retained by the author(s), with first publication rights granted to the journal.

This is an open-access article distributed under the terms and conditions of the Creative Commons Attribution license (http://creativecommons.org/licenses/by/4.0/). 